\title{
TOURISTS' MOTIVATIONS FOR VISITING DARK TOURISM SITES. CASE OF
} ROMANIA

\author{
Andreia Schneider, Silvia Anghel-Vlad, Lucia Negruț, Gheorghe Goje, lulia Para \\ Management Department, Faculty of Economics and Business Administration, West \\ University of Timișoara, Timișoara, Romania
}

andreia.schneider@e-uvt.ro

silvia.vlad@e-uvt.ro

iulia.para@e-uvt.ro

lucia.negrut@e-uvt.ro

gheorghe.goje@e-uvt.ro

\begin{abstract}
Nowadays, tourism plays an essential role in economic growth and development in many countries. Tourists have different travelling motivations and behavioural manifestations, helping tour operators decide suitable for them. Developing a dark tourism niche concept is a necessary step for correct use of it in theory and practice. Dark tourism is an important concept studied in the past twenty years in worldwide literature. This empirical paper aimed to determine the tourists' motivations for travelling to Romania's dark tourism destinations and establishing them. A quantitative research method was applied based on a survey using a non-probabilistic technique based on convenience sampling. Secondary, it was studied the relationship between motivational determinants and tourists' attitude-behaviour in visiting dark tourism sites (Theory of Planned Behaviour, TPB). The survey conducted online was primarily made of 40 items evaluated on the Likert scale. It has been used a sample based on 475 Romanian respondents: $72.3 \%$ who had already visited a dark tourism destination in Romania, and $27.8 \%$ who stated they planned to visit one. The theoretical framework has analysed five constructs as motivational determinants in the relationships with behavioural construct attitude (TPB). The results show support for two of five research hypotheses (H1 and H4). Dark experience (H1) and Unique learning experience (H4) have a significant and positive effect on Attitude. We did not find any significant effect of Engaging entertainment, Casual interest, and Emotional recreation on Attitude. Hence, H2, H3 and H5 are not supported. Based on these results, the government can develop tourism economic and marketing policy to develop dark tourism as important post-communist niche tourism. The practitioners can develop and promote tourism packages and products by applying the correct use of dark tourism sense. The present scientific paper's originality is given by the lack of literature review studies based on empirical research on this topic. Limits of the research and future research directions are also pointed out in the conclusion part.
\end{abstract}

Keywords: dark tourism; sites; motivations; attitude; Theory of Planned Behaviour

JEL Classification: M31; L83; Z31.

\section{Literature review}

The worldwide literature is published in over 171 research study (Light D., 2017), and points of view regarding dark tourism term developed more than two decades ago. Scholars and practitioners worked since the mid-1990s to explain "this fascination with the macabre and morbid" (Hartmann, R. et al., 2018). Thus, studies on motivations for visiting dark tourism sites still represents an "under-researched topic" (Sharpley R. and Stone, 2009). People are getting more and more fascinated and attracted by death, willing and curious to visit places 
where have been disasters, atrocities, violence, paranormal phenomenon, legends, myths, and macabre activities. Knowing precisely why people visit dark tourism sites and places can help develop tourism products, implement marketing strategies to attract tourists and raise awareness of the importance of this type of tourism for the country heritage.

Romania is an Eastern European country with a rich communist history, "communist heritage" (Light D., 2000) and events associated with death, sufferance, violence, sites that can become part of dark tourism destinations. After the revolution, both the visitor's mentality and the tourism area's offer changed, appearing dark tourism niche. People are willing to travel to these sites to see the impact of the communist period, experience "direct and ancestral memories of the brutalities", the 'dark myth' Banaszkiewicz M. et al. (2017), and also helping the local economy. Romania so far does not have a national strategic plan according to develop and promote this type of tourism regarding communist heritage (Master Tourism Plan 2007-2026).

During the times also Dracula's legend attracted the attention of many tourists and academic researchers. Bran Castle and Merry Cemetery from Săpânța are the most known sites for dark tourism at the international level. Therefore, it is only necessary to identify and promote them properly.

In the national academic literature, few studies contribute to the knowledge of this type of tourism niche. Most of them at theoretically and exploratory level such us: emphasis on Dracula's myth from Transylvania (Light D., 2017; Drule M. et al., 2014; Stoleriu O., 2014), communist decline" most violent revolution" (Light D., 2000:161), Romanian heritage for dark tourism (Gabor M.R. and Oltean F.D., 2014), the potential for developing a niche segment (Patrichi I., 2013,), focus on a new form of tourism (Robantu C. and Vasile M., 2014), dark tourism as the regional brand for Transilvania (Ghetau, L. And Esanu, L., 2010). Thus it is a vacuum of empirical researches, especially on motives related to tourists behaviour which are visiting dark sites.

\subsection{Dark tourism definition and typology}

The dark tourism concept was presented for the first time in 1996 by Foley and Lennon (1996:196) in the International Journal of Heritage Studies edition. It was defined as "the presentation and consumption (by visitors) of real and commodified death and disaster sites". At the same time was introduced the term thanatourism by Seaton (1996:240) defined as "travel to a location wholly, or partially, motivated by the desire for actual or symbolic encounters with death, particularly, but not exclusively, violent death".

Fonseca A. et al. (2016:1) mention that during the years, dark tourism phenomenon was described such as: "morbid tourism", "thanatourism", "atrocity tourism", and "black spot".

According to the tourists' motivation, dark tourism has six typologies: 'War/Battlefield Tourism, Disaster Tourism, Prison Tourism, Cemetery Tourism, Ghost Tourism, and Holocaust Tourism" (Fonseca A. et al. 2016). Further, the author Fonseca A. listed and analysed 31 dark tourism sites worldwide, including Bran Castle from the Transylvania region, Romania. She concluded that dark tourism has the power to bring from the past up to present events, is "sharing information and causing emotions, expanding the discussion of the darker side of history and humanity." Seaton (1999) pointed out that death tourism according with the reason for travelling can be: for watching death, to see sites after death has occurred, visiting graves, monuments, "travel to re-enactments" (in Muzdzanani T., 2014).

All in all, dark tourism refers to visiting places (sites, destinations, tourist attractions) that are associated with death, tragedy, suffering, resulting from: natural disasters, revolutions, battles, communist prisons, anthropogenic disasters, crimes, sacrifices, genocide, atrocities, paranormal events, legends, myths. This approach was applied in this research study. 


\subsection{Motivational determinants and Theory of Planned Behaviour (TPB)}

Tourist motivation is an important determinant factor in the decision-making process for travelling. Tarlow (2005) mentioned, 'four basic emotions which interact on a dark tourist's psychological state: insecurity, gratitude, humility and superiority" (cited in Niemelä T., 2010:20). Different motivations conduct tourist behaviour for visiting dark sites: for engaging with post-disaster places (this remains a motive still under-researched, Biran, A. et al., 2014), for curiosity (Foley, 2000), for heritage and history events (Smith, 1996), event validation, education (Hyde and Harman, 2011).

The theory of pull-push factors (psychological - cultural one) is important to be taken into consideration when we try to understand tourists travel motivation and decision (Biran, A. et al., 2014).

Motivational determinants (motives) construct is made of five dimensions: "Dark Experience, Engaging Entertainment, Unique Learning Experience, Casual Interest, Emotional Recreation" (Allman H.R., 2017). The attitude construct is part of the Theory of Planned Behaviour (TPB). This theory is applied "to predict behaviours that are not under complete volitional control" (Ajzen, 1988). A study in China using TPB showed that "attitude, perceived behavioural control, and past behaviours were directly related to the survey participants' travel intentions (Lam and Hsu, 2004)."

These constructs are described below, adapted from Allman H., (2017) and literature, and are included in this research framework (hypothesis).

Dark Experience refers to visiting destinations related to death, suffering, satisfying personal curiosity, fascination with abnormal and bizarre events, and reconnecting to the past's dark events. Engaging Entertainment refers to entertainment value, emotional connection to the location they visit to try something new and something out of the ordinary. Unique Learning Experience focuses on learning, increasing knowledge, and experiencing a part of cultural heritage, history. Casual Interest refers to the individual's opportunity to have an enjoyable time with family/friends, personal safety, natural scenery. Emotional Recreation refers to the chance to meet people with similar interests and to be emotionally refreshed.

Attitude's approach measurement in the actual study is made of attribute regarding dark tourist's behavioural intentions: morbid, interesting, unusual, educational, depressing, emotional, enjoyable, original, sophisticated, useful.

\section{Research methodology}

The empirical paper aimed to study the relationship between motivational determinants and tourists' attitude-behaviour in visiting Romania's dark tourism sites. Secondary, it was essential to find out the most visited dark tourism destination and sites from the country and for what reason.

\subsection{Theoretical framework and research hypotheses}

The theoretical framework is based on a comprehensive literature review used in the previous research studies (Heather Renee Allman 2017, Biran et al. 2014, Bissel 2009) to measure the significant relationship between motivational determinants' primary constructs and the Theory of Planned Behaviour (TPB).

Were developed five hypotheses' statements to study the relationships between the constructs as follows:

Hypothesis 1: Dark Experience has a positive relationship with Attitudes.

Hypothesis 2: Engaging Entertainment has a positive relationship with Attitudes.

Hypothesis 3: Unique Learning Experience has a positive relationship with Attitudes.

Hypothesis 4: Casual Interest has a positive relationship with Attitudes. 
Hypothesis 4: Emotional Recreation has a positive relationship with Attitudes.

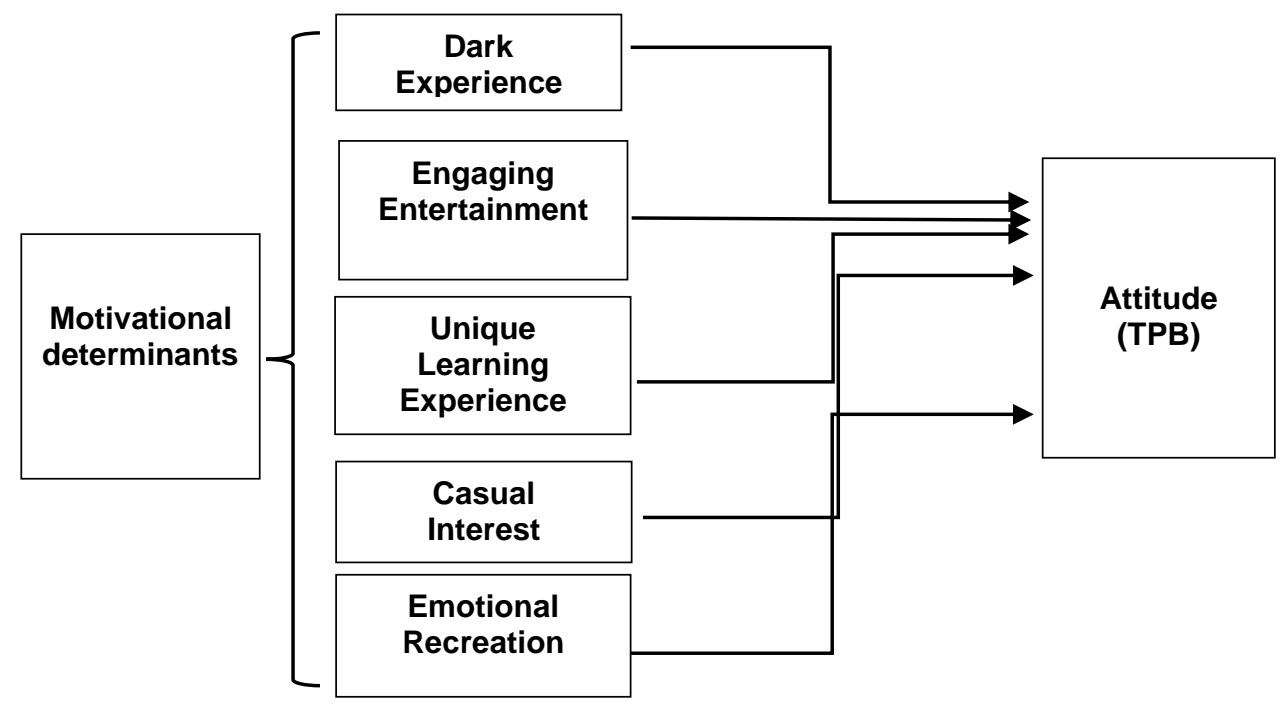

Figure 1. Conceptual research framework adapted from Allman H.R. (2017)

\subsection{Survey instrument and sampling}

In the study were developed two surveys instruments based on the theoretical framework used. One survey was completed by the tourists who have been visited a dark tourism destination or site. The other one was completed by the tourists who have been not visited yet, do not reject the action and intent to visit it. A quantitative research method was applied based on a survey using a non-probabilistic technique based on convenience sampling.

The surveys were conducted online with the support of the website www.isondaje.ro, in MayJuly 2019, from 475 non-rejectors respondents of dark tourism activities, from the West and Central region of the country. Each of the 20 scale items of the first five motivational Dark tourism constructs was developed on a Likert scale questions (1 representing unimportant and five representing important). Each of the ten scale items of construct Attitude was designed on a Likert scale questions (1 representing totally disagree and five representing totally agreed).

Items of Dark tourism construct and Attitude - behaviour construct measurement was adapted from Allman H.R. (2017) research and are listed in Table 2 and Table 3 after the statistical analysis.

An additional question was developed to find out from the respondents the dark tourism destination visited so far or plan to visit it from Romania and analyse it according to its motives.

To increase the research's validity, a pilot test was conducted to check if the questions are correctly made and provide feedback to improve the questionnaires. Ten persons were involved (academics and non-academics). We received attentions to be more specific in the question 9 sentence related to analysing the dark tourism sites visited or intended to. The respondents had word issues understanding often with those ten motives listed. We revised them by making short propositions. 


\section{Results}

\subsection{Sample Structure}

We interviewed a total sample of 475 non-rejectors of dark tourism activities: $343(72.3 \%)$ who had already visited a dark tourism location in Romania, and 132 (27.8\%) who said they planned to visit one (i.e., they do not reject the activity). The two sub-groups are similar in their socio-eco-demographic structure, except respondents who did not visit any dark tourism sites (but plan to visit) are more frequent in the under-25 age category (see Table 1). We consider this to be normal, as they probably did not find the time to visit any dark tourism sites. Therefore, we did not consider this as an influence on our study. Otherwise, the structure of the two groups is similar. All data were analysed using SPSS 23 statistics software.

Table 1 Sample Structure

\begin{tabular}{|c|c|c|c|c|c|c|c|}
\hline \multirow{3}{*}{ Sample structure } & \multirow{3}{*}{ Sample structure } & \multirow{2}{*}{\multicolumn{2}{|c|}{ Total sample }} & \multicolumn{4}{|c|}{ Visited dark tourism site } \\
\hline & & & & \multicolumn{2}{|c|}{ Yes } & \multicolumn{2}{|c|}{ Plan to visit } \\
\hline & & \multicolumn{2}{|c|}{ N $\%$} & $N$ & $\%$ & $N$ & $\%$ \\
\hline Total sampl & & 475 & $100.0 \%$ & 343 & $100.0 \%$ & 132 & $100.0 \%$ \\
\hline \multirow{6}{*}{ Age } & <25 years old & 136 & $28.6 \%$ & 81 & $23.6 \%$ & 55 & $41.7 \%$ \\
\hline & 26 - 35 years old & 170 & $35.8 \%$ & 131 & $38.2 \%$ & 39 & $29.5 \%$ \\
\hline & 36 - 45 years old & 92 & $19.4 \%$ & 70 & $20.4 \%$ & 22 & $16.7 \%$ \\
\hline & 46 - 55 years old & 51 & $10.7 \%$ & 38 & $11.1 \%$ & 13 & $9.8 \%$ \\
\hline & 56 - 65 years old & 21 & $4.4 \%$ & 19 & $5.5 \%$ & 2 & $1.5 \%$ \\
\hline & $65+$ years old & 5 & $1.1 \%$ & 4 & $1.2 \%$ & 1 & $0.8 \%$ \\
\hline \multirow[t]{2}{*}{ Gender } & Female & 101 & $21.3 \%$ & 70 & $20.4 \%$ & 31 & $23.5 \%$ \\
\hline & Male & 374 & $78.7 \%$ & 273 & $79.6 \%$ & 101 & $76.5 \%$ \\
\hline \multirow{4}{*}{ Income } & "Less than 1000 lei & 66 & $13.9 \%$ & 445 & $13.1 \%$ & 221 & $15.9 \%$ \\
\hline & Between 1001 and 2500 lei & 133 & $28.0 \%$ & 98 & $28.6 \%$ & 35 & $26.5 \%$ \\
\hline & Between 2501 and 3000 lei & 104 & $21.9 \%$ & 74 & $21.6 \%$ & 30 & $22.7 \%$ \\
\hline & More than 3500 lei & 172 & $36.2 \%$ & 126 & $36.7 \%$ & 46 & $34.8 \%$ \\
\hline \multirow{2}{*}{ Residence } & "Urban & 383 & $80.6 \%$ & 277 & $80.8 \%$ & 106 & $80.3 \%$ \\
\hline & Rural & 92 & $19.4 \%$ & 66 & $19.2 \%$ & 26 & $19.7 \%$ \\
\hline
\end{tabular}

\subsection{Constructs and Hypotheses}

To discover the basic structure of the constructs investigated in this study, factor analysis was performed. Both constructs (Dark Tourism and Attitude) were subjected to principal component analysis (PCA) with Varimax rotation using the eigenvalue criterion greater than 1.00. According to Hair et al. (1998), factor loading for each item should be 0.50 or higher. Based on the research conducted by Allman (2017), Dark Tourism includes four dimensions: Dark experience, Engaging entertainment, Unique learning experience and Casual interest. The factor analysis we conducted on the 20 items of this construct (five items for each dimension) revealed five dimensions, appropriately named as Dark experience (1), Engaging entertainment (2), Casual interest (3), Unique learning experience (4) and Emotional recreation (5) (see Table 2). 


\begin{tabular}{|c|c|c|c|c|c|}
\hline \multicolumn{6}{|c|}{ Table 2 Factor analysis and reliability of the Dark Tourism construct } \\
\hline Dimension/Items & (1) & (2) & (3) & (4) & (5) \\
\hline \multicolumn{6}{|l|}{ Dark experience (1) } \\
\hline $\begin{array}{l}\text { To satisfy personal curiosity about how } \\
\text { the victims died }\end{array}$ & 0.774 & & & & \\
\hline To witness the act of death and dying & 0.781 & & & & \\
\hline $\begin{array}{l}\text { To satisfy my fascination with abnormal } \\
\text { and bizarre events }\end{array}$ & 0.734 & & & & \\
\hline $\begin{array}{l}\text { To visit a well-recognised location that is known } \\
\text { to be home to dark experiences }\end{array}$ & 0.634 & & & & \\
\hline To reconnect to the dark events & 0.597 & & & & \\
\hline \multicolumn{6}{|l|}{ Engaging entertainment (2) } \\
\hline Travel as a hobby & & 0.733 & & & \\
\hline To have some fun and entertainment & & 0.668 & & & \\
\hline To change pace and get away from routine & & 0.716 & & & \\
\hline To try something new & & 0.635 & & & \\
\hline To try something out of the ordinary & & 0.613 & & & \\
\hline \multicolumn{6}{|l|}{ Casual interest (3) } \\
\hline To have an enjoyable time with family/friends & & & 0.591 & & \\
\hline Natural scenery & & & 0.545 & & \\
\hline Service quality & & & 0.829 & & \\
\hline Personal safety & & & 0.813 & & \\
\hline Reputation and fame* & & & 0.613 & & \\
\hline \multicolumn{6}{|l|}{ Unique learning experience (4) } \\
\hline To increase knowledge & & & & 0.802 & \\
\hline $\begin{array}{l}\text { To experience a part of my heritage } \\
\text { To experience a place(s) many people have } \\
\text { not been to or wish to visitt* }\end{array}$ & & & & 0.849 & \\
\hline \multicolumn{6}{|l|}{ Emotional recreation (5) } \\
\hline To meet people with similar interests & & & & & 0.809 \\
\hline To be emotionally refreshed & & & & & 0.749 \\
\hline Eigenvalue & 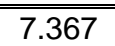 & 2.194 & 1.556 & 1.270 & 1.004 \\
\hline$\%$ of Variance & 36.828 & 10.971 & 7.782 & 6.352 & 5.020 \\
\hline Cronbach's alpha & 0.818 & 0.843 & 0.822 & 0.813 & 0.721 \\
\hline Bartlett's Test of Sphericity & 0.000 & & & & \\
\hline Kaiser-Meyer-Olkin (KMO) & 0.886 & & & & \\
\hline
\end{tabular}

As Table 2 shows, one item was deleted during the factor analysis procedure due to its factor loading being lower than the accepted value of 0.50 (Hair et al., 1998). All remaining items had a factor loading greater than 0.50 , ranging between 0.545 and 0.849 . The eigenvalue for all five factors (dimensions) of the Dark tourism construct ranged between 7.367 and 1.004. The five factors cumulatively explained $66.95 \%$ of the data's variance with a KMO value of 0.886 and significant Bartlett's Test of Sphericity. Furthermore, when testing internal consistency for each dimension of the Dark tourism construct, the reliability analysis revealed that all five dimensions had Cronbach's alpha scores higher than 0.700 (see Table 2). According to Nunnally (1978), a measurement scale is reliable if the value of Cronbach's alpha coefficient is equal to or higher than 0.700 .

Only one dimension was extracted from 10 items measuring the Attitude since the solution cannot be rotated. The eigenvalue extracted was 2.455 and captured $49.11 \%$ of the data's variance with a KMO value of 0.756 and significant Bartlett's Test of Sphericity. Five items were deleted during the scale purification (Morbid, Unusual, Depressing, Fun and Sophisticated), final Cronbach alpha score is 0.734 . 
Table 3 Discriminant validity assessment

\begin{tabular}{|c|c|c|c|c|c|c|}
\hline Construct/ltems & (1) & (2) & (3) & (4) & (5) & (6) \\
\hline \multicolumn{7}{|l|}{ Dark experience (1) } \\
\hline $\begin{array}{l}\text { To satisfy personal curiosity about how } \\
\text { the victims died }\end{array}$ & 0.773 & 0.321 & 0.179 & 0.212 & 0.295 & 0.363 \\
\hline To witness the act of death and dying & 0.812 & 0.208 & 0.195 & 0.229 & 0.351 & 0.369 \\
\hline $\begin{array}{l}\text { To satisfy my fascination of abnormal } \\
\text { and bizarre events }\end{array}$ & 0.761 & 0.479 & 0.256 & 0.166 & 0.370 & 0.300 \\
\hline $\begin{array}{l}\text { To visit well-recognized location that are } \\
\text { known to be home to dark experiences }\end{array}$ & 0.739 & 0.462 & 0.340 & 0.355 & 0.310 & 0.422 \\
\hline To reconnect to the dark events & 0.722 & 0.273 & 0.257 & 0.396 & 0.358 & 0.482 \\
\hline \multicolumn{7}{|l|}{ Engaging entertainment (2) } \\
\hline Travel as a hobby & 0.206 & 0.677 & & 0.362 & 0.226 & 0.202 \\
\hline ome fun and entertainment & 0.252 & 0.748 & & 0.152 & & 0.279 \\
\hline $\begin{array}{l}\text { To change pace and get away from } \\
\text { routine }\end{array}$ & 0.260 & 0.814 & 0.520 & 0.315 & 0.470 & 0.449 \\
\hline To try something new & 0.500 & 0.849 & 0.513 & 0.436 & 0.459 & 0.416 \\
\hline To try something out of the ordinary & 0.529 & 0.822 & 0.458 & 0.347 & 0.481 & 0.363 \\
\hline \multicolumn{7}{|l|}{ Casual interest (3) } \\
\hline $\begin{array}{l}\text { To have an enjoyable time with } \\
\text { family/friends }\end{array}$ & 0.127 & 0.454 & 0.759 & 0.275 & 0.354 & 0.219 \\
\hline Natural scenery & 0.311 & 0.574 & 0.789 & 0.461 & 0.328 & 0.399 \\
\hline & 0.298 & 0.476 & & 0.310 & & 0.326 \\
\hline Personal safety & 291 & 0.436 & 338 & 0.319 & 0.354 & 0.290 \\
\hline \multicolumn{7}{|l|}{ Unique learning experience (4) } \\
\hline To increase knowledge & 0.365 & 0.424 & 0.389 & 0.918 & 0.278 & 0.529 \\
\hline To experience a part of my own heritage & 0.284 & 0.334 & 0.383 & 0.918 & 0.236 & 0.502 \\
\hline \multicolumn{7}{|l|}{ Emotional recreation (5) } \\
\hline To meet people with similar int & 0.370 & 0.449 & 0.330 & 0.203 & 0.884 & 0.272 \\
\hline To be emotior & .412 & 0.489 & 0.417 & 0.292 & 0.884 & 0.330 \\
\hline \multicolumn{7}{|l|}{ Attitude (6) } \\
\hline Interesting & 418 & 0.366 & 0.273 & 0.382 & 0.176 & 0.748 \\
\hline Educ & 0.294 & 0.189 & 0.164 & 0.488 & 0.158 & 0.761 \\
\hline Emot & 0.358 & 0.185 & 0.171 & 0.284 & 0.245 & 0.546 \\
\hline Original & 0.369 & 0.501 & 0.469 & 0.345 & 0.306 & 0.666 \\
\hline Useful & 0.348 & 0.233 & & 0.444 & 0.322 & 0.759 \\
\hline
\end{tabular}

To assess convergent and discriminant validity, we used Pearson's correlation coefficient. Results revealed that the items used to measure each construct are correlated two by two; the significance level is lower than the accepted limit of 0.05 (Bagozzi et al., 1991). Furthermore, each scale's items used to measure a construct are most strongly correlated with that construct. For each measurement scale, Pearson's correlation coefficient recorded the highest values in the construct measured by it (see Table 3). Hence, convergent and discriminant validity was achieved.

Table 4 Standardised coefficients $(\beta)$ for the research model

\begin{tabular}{lccc}
\hline Research Hypothesis & $\begin{array}{c}\text { Standardised } \\
\text { coefficients }(\boldsymbol{\beta})\end{array}$ & $\begin{array}{c}\text { Significance } \\
\text { level }(\mathbf{p})\end{array}$ & $\begin{array}{c}\text { Hypothesis } \\
\text { testing result }\end{array}$ \\
\hline \hline Dark experience $\rightarrow$ Attitude $(\mathrm{H} 1)$ & 0.302 & 0.000 & $\begin{array}{c}\text { Supported } \\
\text { Engaging entertainment } \rightarrow \text { Attitude } \\
\text { (H2) }\end{array}$ \\
Casual interest $\rightarrow$ Attitude $(\mathrm{H} 3)$ & 0.059 & 0.228 & Not supported \\
\hline \hline
\end{tabular}




\begin{tabular}{llllc}
\hline \hline Unique learning experience $\rightarrow$ & 0.391 & 0.000 & Supported \\
Attitude $(\mathrm{H} 4)$ & & & Not supported \\
Emotional recreation $\rightarrow$ Attitude $(\mathrm{H} 5)$ & 0.036 & 0.402 & N
\end{tabular}

Multiple regression analysis was performed to test the research hypotheses, namely the relationship between the dependent variable (Attitude) and independent variables (Dark experience, Engaging entertainment, Casual interest, Unique learning experience and Emotional recreation) (Hair et al., 1998).

Table 4 presents the standardised coefficients $(\beta)$ and their significance levels for each hypothesis. As shown in Table 4, we found support for two of five research hypotheses $(\mathrm{H} 1$ and $\mathrm{H} 4$ ) at a significance level lower than 0.05. Dark experience and Unique learning experience have a significant and positive effect on Attitude $(\beta=0.302, p=0.000 ; \beta=0.391$, $p=0.000)$. We did not find any significant effect of Engaging entertainment, Casual interest, and Emotional recreation on Attitude $(p=0.228, p=0.120$ and $p=0.402)$. Hence, H2, H3 and H5 are not supported.

Table 5 presents the Average scores calculated to determine the most desired dark tourism sites visited or plan to visit from Romania. It has been listed 20 sites where the respondents visited or intended to. Below are presented average scores only for the most listed dark tourism destinations with the motives named.

Table 5 Average scores of the most desired dark tourism sites visited or planned to

\begin{tabular}{|c|c|c|c|c|c|}
\hline $\begin{array}{l}\text { Motives for } \\
\text { visiting or plan } \\
\text { to visit a dark } \\
\text { tourism site } \\
\text { from Romania }\end{array}$ & $\begin{array}{l}\text { The Merry } \\
\text { Cemetery } \\
\text { from } \\
\text { Săpânța } \\
N=177\end{array}$ & $\begin{array}{l}\text { Bran } \\
\text { Castle } \\
\mathrm{N}=130\end{array}$ & $\begin{array}{l}\text { Sighet } \\
\text { Memorial } \\
\text { Museum } \\
\mathrm{N}=71\end{array}$ & $\begin{array}{l}\text { Victory } \\
\text { Square, } \\
\text { Timișoara } \\
\mathrm{N}=28\end{array}$ & $\begin{array}{l}\text { Revolution } \\
\text { Memorial } \\
\text { Timișoara } \\
\mathrm{N}=28\end{array}$ \\
\hline $\begin{array}{l}\text { To believe, I } \\
\text { have to see }\end{array}$ & 3.07 & 3.12 & 2.72 & 2.86 & 2.98 \\
\hline $\begin{array}{l}\text { My interest in } \\
\text { such a site }\end{array}$ & 3.49 & 3.69 & 3.68 & 3.50 & 3.64 \\
\hline $\begin{array}{l}\text { The notoriety of } \\
\text { the site }\end{array}$ & 4.06 & 3.82 & 3.55 & 3.57 & 3.32 \\
\hline $\begin{array}{l}\text { Empathy with } \\
\text { the victims }\end{array}$ & 2.88 & 2.74 & 3.87 & 3.57 & 3.64 \\
\hline $\begin{array}{l}\text { So I can tell } \\
\text { more about the } \\
\text { others }\end{array}$ & 3.43 & 3.24 & 3.51 & 3.21 & 3.46 \\
\hline $\begin{array}{l}\text { I'm learning } \\
\text { more from what } \\
\text { happened }\end{array}$ & 3.67 & 3.75 & 4.30 & 3.68 & 4.04 \\
\hline $\begin{array}{l}\text { Emotional } \\
\text { experience }\end{array}$ & 3.58 & 3.31 & 3.83 & 3.29 & 3.79 \\
\hline Curiosity & 4.36 & 4.31 & 4.01 & 4.00 & 3.96 \\
\hline $\begin{array}{l}\text { Contemplation } \\
\text { of life and death }\end{array}$ & 3.49 & 2.97 & 3.44 & 2.71 & 3.64 \\
\hline $\begin{array}{l}\text { To have a } \\
\text { correct picture } \\
\text { of } \quad \text { what } \\
\text { happened }\end{array}$ & 3.72 & 3.75 & 4.44 & 3.89 & 4.07 \\
\hline
\end{tabular}

These results are discussed in the following section, together with research implications. Also, the limitations and future research directions of this research are presented. 


\section{Conclusions and Discussions}

The dark tourism niche becomes more and more attractive for many people because of the opportunity to learn, satisfy curiosity, discover the heritage, history related to death events, catastrophic events, paranormal activities, mystery, and bloody legends.

The first significant result of the empirical research was given by the Dark experience construct that has a significant and positive effect on Attitude. This result is not surprising because it was founded in previous research by Bissell (2009) and Allman H.R. (2017). This indicates that the tourist is curious about and want this thematic experience (see Table 5).

The second significant result is that the Unique Learning Experience construct has a substantial and positive effect on Attitude. This means that respondents are travelling for educational purposes. This being also mentioned when they had to give motives for their answer about the destination named (see Table 5).

The third significant study result pointed out the most listed motives by the respondents who visited or planned to visit Romania's dark tourism site. Motives scored with an average of more than four are Curiosity; To have a correct picture of what happened; I'm learning more from what happened; The notoriety of the sites (see Tabel 5).

According to these motives, the dark destinations listed by the respondents are The Merry Cemetery from Săpânța (listed by 177 respondents), Bran Castle (listed by 130 respondents), Sighet Memorial Museum (listed by 71 respondents), Victory Square, Timișoara (listed by 28 respondents), Revolution Memorial Timișoara (listed by 28 respondents) and others sites like Forest Hoia-Baciu, Union Square Timișoara, Liberty Square Timișoara, Corvinilor Castle, Prison Doftana, Fortress Poenari, Aiud Pain Memorial, Mine Anina, Transfăgărășan, Prison Jilava, Mărășești Mausoleum, Pitești Prison, Fortress Sarmizegetusa Communist prison Râmnicu-Sărat, Black Church Brașov, Jewish cemetery (listed by 41 respondents). Empathy with the victims is an influential motivational factor when visiting museum and locations related to the dead, suffering, revolution.

These results can help travel tourism agencies develop travel packages to encourage people to visit these dark tourist destinations. The destination management (local authorities, museums) can also develop marketing and tourism policy and strategies to attract tourists in this dark tourism direction niche.

The historical sites where people died or suffered are the most listed dark tourism destination. We must consider that $38.2 \%$ of respondents are youngers up to 35 years old, and most of them chose Bran Castle as a dark tourism destination due to Dracula's legend. The anti-communist revolution makes Timisoara an authentic, ongoing dark tourism destination. Estimated numbers showed, before COVID-19 restrictions, that in 2021 Timisoara will have 1.5 mil visitors annually, and about 30 mil people from Europe have heard of TM2021 - Cultural Capital of Europe (postponed by 2023).

A limit of the research was given by the restricted region allocated to the data collection. Extend study in the other regions from Romania. A probabilistic method can help develop a national strategy on dark tourism destinations and pin Romania on the world's dark tourism map niche. Future directions regard the Theory Planned Behaviour constructs (Behavioural Intentions, Subjective Norm, Perceived Behavioural Control). If the study is replicated, considering this construct will raise the knowledge of tourist's motivational behaviour in visiting dark destinations. Also, to investigate the link between the motivations and postcommunist country desire to visit a dark destination and sites.

\section{References}

1.Ajzen, I. (1988) Attitudes, personality, and behaviour, Chicago: Dorsey Press.

2.Allman, H.R., (2017) Motivations and intentions of tourists to visit dark tourism locations, Graduate 
Theses and Dissertations. 15243. Available: https://lib.dr.iastate.edu/etd/15243.

3.Bagozzi, R.P., Yi, Y. \& Philips, L.W. (1991) Assessing Construct Validity in Organizational Research, Administrative Science Quarterly, Vol. 36, No. 3, pp. 421-458.

4.Banaszkiewicz M. et al. (2017) Tourism in (Post)socialist Eastern Europe, Journal of Tourism and Cultural Change, 15:2, 109-121, https://doi.org/10.1080/14766825.2016.1260089

5.Biran, A., et al. (2014) Consuming post-disaster destinations: the case of Sichuan, China. Annals of Tourism Research, 47, 1-17.

6.Bissell, L.J. (2009) Understanding Motivation and Perception at Two Dark Tourism Attractions in Winnipeg, MB Thesis. University of Manitoba. Available: https://mspace.lib.umanitoba.ca/bitstream/handle/1993/29742/Bissell Understanding motivation.pdf ?sequence $=1$.

7.Foley, M \& Lennon, JJ. (1996) JFK and dark tourism: a fascination with assassination. International Journal of Heritage Studies (2):198-211. https://doi.org/10.1080/13527259608722175.

8.Fonseca et al. (2016) Dark Tourism: Concepts, Typologies and Sites, Journal and Tourism Research Hospitality, S2 http://dx.doi.org/10.4172/2324-8807.S2-002.

9.Gabor, M.R. and Oltean, F.D. (2014) Romanian heritage for dark tourism as alternative for sustainable and economic development, vol. I-Economy and Management.

10. Ghetau, L. And Esanu, L., (2010) Dark tourism in Romania: from concept to reality, WIT Transactions on Ecology and the Environment, Vol 139, Sustainable Tourism IV p.581- 590, ISSN 1743-3541 (online), doi:10.2495/ST100501.

11. Hair, J. F., Black, W. C., Babin, B. J., Anderson, R. E., \& Tatham, R. L. (1998) Multivariate data analysis (Vol. 5, No. 3, pp. 207-219). Upper Saddle River, NJ: Prentice-Hall.

12.Hartmann, R., et al. (2018), The history of dark tourism Journal of Tourism History.

13. Hyde, K.F. and Harman, S. (2011), Motives for a secular pilgrimage to the Gallipoli battlefields, Tourism Management, Vol. 32, pp. 1343-1351.

14.Lam, T., and Hsu, C. (2004) Theory of planned behaviour: potential travellers from China, Journal of Hospitality \& Tourism Research, 28(4), 463-482.

15.Lennon, J \& Foley, M. (2000) Dark tourism: the attraction of death and disaster. New York: TJ International.

16.Light, D. (2017) Progress in dark tourism and thanatourism research: An uneasy relationship with heritage tourism, Tourism Management, Volume 61, Pages 275-301, ISSN 0261-5177, DOI: https://doi.org/10.1016/i.tourman.2017.01.011.

17.Light, D. (2017) The undead and dark tourism: Dracula tourism in Romania, in G. Hooper and J.J. Lennon (eds) Dark Tourism: Practice and Interpretation, Routledge, Abingdon, 121-133.

18.Light, D., (2000) An unwanted past: contemporary tourism and the heritage of communism in Romania. International Journal of Heritage Studies, 6, 145-160.

19.Light, D., (2000) Gazing on communism: heritage tourism and post-communist identities in Germany, Hungary and Romania, Tourism Geographies 2(2), 157-176.

20.Mudzanani T. (2014) Why is Death so Attractive? An Analysis of Tourists' Motives for Visiting the Hector Peterson Memorial and Museum in South Africa, Mediterranean Journal of Social Sciences MCSER Publishing, Vol 5 No 15 Rome-Italy, ISSN 2039-2117 (online) DOI:10.5901/mjss.2014.v5n15p570.

21.Niemelä T. (2010) Motivation Factors in Dark Tourism. Case: House of Terror, Bachelor's Thesis in Nature and Soft Adventure Tourism, Lahti University of Applied Sciences Degree Programme in Tourism and Hospitality Management.

22.Nunnally, J. (1978) Psychometric theory, 2, 1202-1208.

23.Patrichi, I.C. (2013) Dark Tourism - A Niche Segment For The Romanian Tourism, Romanian Economic Business Review, Romanian-American University, vol. 8(4.1), pages 351-358, December. 24.Rabontu, C.I. and Vasile M.C. (2014) Dark Tourism - New Form Of Tourism In Romania, Annals Economy Series, Constantin Brancusi University, Faculty of Economics, vol. 6, pages 269-273, December.

25.Seaton, A. (1996) Guided by the dark: from thanatopsis to thanatourism. International Journal of Heritage Studies (2):234-244. DOI: https://doi.org/10.1080/13527259608722178.

26.Sharpley, R \& Stone, P (eds). (2009) The darker side of travel: the theory and practice of dark tourism. Bristol: Channel View.

27.Smith, VL. (1996) War and its tourist attractions. In A. Pizan \& Y. Manfeld (eds), Tourism, crime and international security issues. Brisbane: John Wiley and Sons 
28.Stoleriu, O.M. (2014) Dracula tourism and dark geographies of Romania, International Antalya hospitality tourism and travel research, Conference proceedings, Antalya, Turkey December 9-12, CD-ROM ISBN: 978-605-4483-22-8; Akdeniz University, Tourism Faculty, pp.44-69. Volume 10, 2018 - Issue 3, DOI: https://doi.org/10.1080/1755182X.2018.1545394.

29. Romania Tourism Master Plan 2007-2026: http://turism.gov.ro/web/wpcontent/uploads/2017/05/masterplan_partea1.pdf

30. Timisoara 2021 - European Capital of Culture, Candidate City, European Capital of Culture Association

https://www.capitalaculturala2021.ro/Files/dosare/timisoara/TM2021\%20Bidbook RO 0610digital.pdf 